\title{
SzeleStra: új rétegtani kutatások a Szeletien kultúra névadó lelőhelyén
}

\author{
Mester Zsolt, Szolyák Péter, Lengyel György, Ringer Árpád
}

Kivonat

Abstract

\section{Kulcsszavak}

Keywords

Szerző • Author

Hivatkozás • Cite as

Kézirat történet • Article history

Jogok • Copyright

\begin{abstract}
A Szeletien kultúra névadó lelőhelyeként a keleti Bükkben, a Szinva-völgy felett nyíló Szeleta-barlang a nemzetközi kutatásban egyik legismertebb paleolitikus lelőhelyünk. Levéleszközökkel jellemzett leletanyagának kulturális és kronológiai besorolása, régészeti értékelése többször változott a kutatástörténet során az Európa paleolitikumáról alkotott kép függvényében. A mindenkori vitákban nehezítette az érvelést, hogy a barlang feltárása 1906-tól napjainkig - olykor több évtizedes kihagyásokkal - különböző kutatók irányítása alatt zajlott, mégis mindenki a Kadić Ottokár által kialakított sztratigráfia keretei közé próbálta beilleszteni megfigyeléseit. Az ezredforduló óta a Szeletien kultúra vonatkozásában előtérbe került a kronológiai helyzetének kérdése, köszönhetően az egyre szaporodó radiokarbon dátumoknak. Világossá vált, hogy a Szeleta esetében ezeket a problémákat nem lehet érdemben vizsgálni a meglévő sztratigráfia bizonytalanságai miatt. 2012-ben új rétegtani kutatás indult a barlang előterén, amelynek célja egy teljesebb rétegsor kialakítása és annak komplex természettudományos vizsgálata.
\end{abstract}

\section{SzeleStra: new stratigraphical research at the eponymous site of the Szeleta culture}

One of our most widely known Palaeolithic site is the eponymous Szeleta-cave above the Szinva brook, in the Bükk Mountains of Hungary. The chronological and cultural interpretation of its findings fell under the development of the European prehistoric studies. The ever-changing debate suffered by a serious obstacle: many researchers worked in the cave since 1906, but only Ottokar Kadić's system of strata were used in the interpretations. The stratigraphy and chronology of the site regained interest around the turn of the millenium. With the advent of new radiocarbon dates, it became obvious that the stratigraphical data at hand are dubious, at least. In 2012 , we initiated a new project in the cave foreground, to uncover an exhaustive stratigraphy for different scientific analyses.

\section{Szeleta-barlang, kronológia, rétegtani kutatás}

Szeleta cave, chronology, stratigraphy

Mester Zsolt, Eötvös Loránd Tudományegyetem, Régészettudom nyi Intézet, H-1088 Budapest, Múzeum krt. 4/B Szolyák Péter, Herman Ottó Múzeum, H-3529 Miskolc, Görgey A. út 28.

Lengyel György, Miskolci Egyetem, Történettudományi Intézet, H-3515 Miskolc-Egyetemváros Ringer Árpád, Miskolci Egyetem, Történettudományi Intézet, H-3515 Miskolc-Egyetemváros

Mester, Zs., Szolyák, P., Lengyel, Gy., Ringer, Á. (2013) SzeleStra: új rétegtani kutatások a Szeletien kultúra névadó lelőhelyén (SzeleStra: new stratigraphical research at the eponymous site of the Szeleta culture). Litikum 1:67-72. https://doi.org/10.23898/litikuma0005

Érkezés | Received: 2013. 10. 10. Elfogadás | Accepted: 2013. 10. 15. Közzététel | Published: 2013. 12. 10.

() Az egyes szerző(k). Ez egy nyílt hozzáférésű publikáció, amit a Creative Commons 4.0 licensze véd. A termék szabadon használható, terjeszthető és sokszorosítható az eredeti szerző és forrás megjelölése mellett. | This is an open-access article distributed under the terms of the Creative Commons Attribution License, which permits unrestricted use, distribution, and reproduction in any medium, provided the original author and source are credited.

\section{Bevezetés}

A nemzetközi kutatásban a legtöbbször hivatkozott őskőkori régészeti lelőhelyünk a Szeleta-barlang. Ez annak köszönhető, hogy leletanyaga egyedülálló, és névadó lelőhelye egy olyan régészeti kultúrának, amely általános vélekedés szerint a középső és a felső paleolitikum közötti átmenetet reprezentálja (Allsworth-Jones 1986). A barlang rétegeiből feltárt, pattintott kövekből álló leletegyüttesek kronológiai helyzetéról és kulturális hovatartozásáról azonban megoszlanak a vélemények (Ringer 1989; Svoboda, Simán 1989; Simán 1990; 1995; Adams 1998; Ringer, Mester 2000; 2001; Ringer 2002; 2008-2009; Ringer, Szolyák 2004; Lengyel-Mester 2008; Lengyel et al. 2008-2009). Mivel a barlang kitöltésének nagy részét kiásták az 1906 óta lezajlott ásatásokon (Mester
2002), a bizonytalanságok feloldásához a megmaradt eredeti kitöltés kulcsfontosságú. Ma már egyre több természettudományos módszer áll rendelkezésre a barlang mint régészeti lelőhely képződésének értelmezéséhez, ami közelebb vihet a leletek és a rétegek helyes időrendi besorolásához. A 2012ben elkezdődött feltárások ehhez akarnak új eredményekkel hozzájárulni.

\section{Szeleta-barlang}

A Szeleta a Bükk hegység keleti oldalán nyíló Szinva-völgy északi sziklafalában található. A 349 m tszf. magasságban nyíló, összesen 115 m hosszú üregrendszer középső triász időszaki mészkőben alakult ki (Fehérkői Mészkő Formáció) (Pelikán 2002: 38; Székely 2002: 190), amelynek a kora kb. 230 

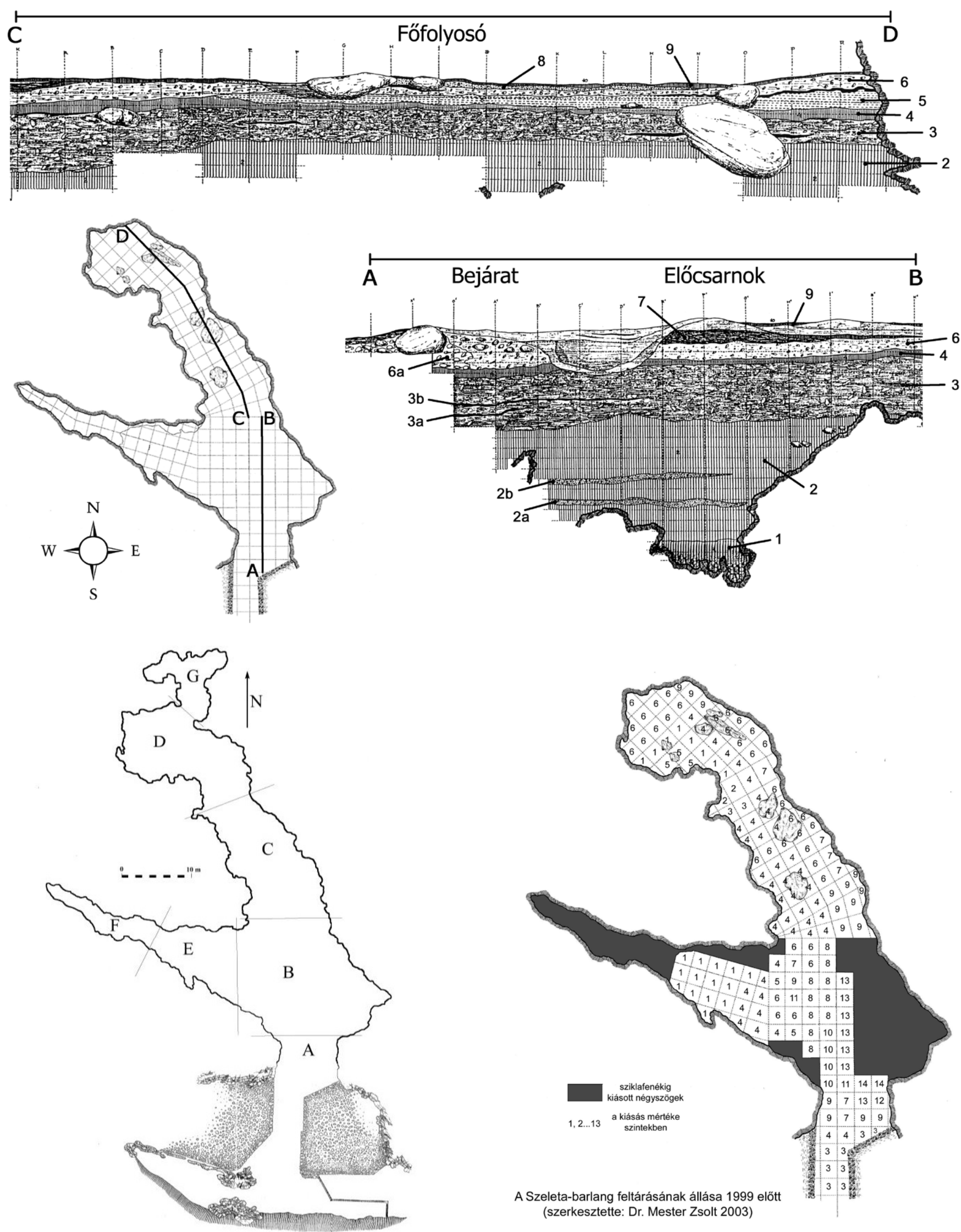

1. ábra (fent). A barlang rétegsorának tagolása. Lengyel-Mester 2008, fig. 2 nyomán, módosítva. 2. ábra (balra lent). A barlang alaprajza és az üreg tagolása. Kadić 1915: XIII tábla nyomán szerkesztette: Szolyák Péter. 3. ábra (jobbra lent). A barlang feltártságának mértéke 1999-ig. A négyszögekben szereplő számok a kiásott szintek számát jelzi (1 szint $=0,5 \mathrm{~m})$. A szürkével színezett négyszögeket a sziklafenékig kiásták. Szerkesztette Mester Zs. 2003. //

Figure 1 (top). Stratigraphical divisions in the cave. Modified after Lengyel-Mester 2008, fig. 2. Figure 2 (bottom left). Plan and division of the cave. Edited after Kadić 1915: Tab. XIII by Péter Szolyák. Figure 3 (bottom right). Excavations in the cave until 1999. Numbers in the grid denote the number of archaeological levels excavated (one level = 0,5 m). The grey units are cleared to the rock bottom. Edited by Zsolt Mester, 2003. 
millió év. A barlang régészeti kutatása 1906-ban indult meg. Ekkor született meg a barlangnak az a tagolása, amelyet továbbra is használunk (2. ábra).

Az Előcsarnokban 12,5 m vastag üledék nagy részét az első ásatási sorozat végéig, 1913-ig eltávolították (Kadić 1915). A rétegsorban kilenc réteget különböztettek meg, alulról felfelé számozva (1. ábra). A kitöltést a barlangnak csak két részén ásták ki a fenékig: az Előcsarnok jobb oldali felén és a Mellékfolyosó majdnem teljes hosszában (3. ábra). Az Előcsarnok bal oldali felében és a Főfolyosó jobb oldalán már csak a 2-es réteg található meg érintetlenül. A Főfolyosó bal oldalán azonban még a 3-as réteg is kutatható. A barlang előterén csak egy keskeny sávban ástak le, s a terasz nagy része régészetileg kutatatlan maradt, mert ott halmozták fel a kitöltésből kiásott mészkőblokkokat (Kadić 1915: 158) (ld. 2. ábra).

A régészeti leletanyag a feltárt területhez viszonyítva kevés, ennek ellenére igen jelentős. A leggyakoribb eszköz a bifaciálisan megmunkált levél alakú típus: hegy és kaparó (Kadić 1915; Vértes 1965). Ezek morfológiai jellemzőinek változása a rétegsor településének rendjében arra utalt, hogy a régészeti anyag egy kultúra korai fázisából kiindulva a fejlett fázisának kialakulását mutatja átmenete(ke)n keresztül (Kadić 1915; 1934; Hillebrand 1935; Vértes 1965; Ringer 1989). $\mathrm{Az}$ egyes rétegekben azonban együtt is megjelennek egymástól eltérő régészeti kultúrákra jellemző kőeszköztípusok (Ringer-Mester 2000; 2001). Ennek magyarázata lehet a kultúrák egymásra hatása vagy a leletek keveredése a rétegek között. A kultúrák egymásra gyakorolt hatása, illetve egy-egy felső paleolitikus eszköztípus korai megjelenése mellett érvel Ringer Árpád (2008-2009), aki először vetette fel, hogy a barlang rétegsorában egymással kronológiailag párhuzamos kultúrák eszközeit tárták fel (Ringer-Mester 2000: 266-268).

Az a feltételezés, hogy a barlang egyes rétegei erősen bolygatottak lehetnek, abból a megfigyelésből indult ki, hogy a levéleszközök egy részén koptatottság (Gábori 1982: 5) és csorbulások figyelhetôk meg, amiket okozhatott a fagy (krioturbáció - Ringer 1989: 224) vagy a barlangi medvék (Lengyel et al. 2008-2009: 18). A klimatikus hatások következtében fellépett rétegzavarok is eredményezhették a leleteknek az üledéken belüli elmozdulását (Lengyel-Mester 2008).

Magának a Szeletien kultúrának a helyzete is felvet számos kérdést a Szeleta rétegsorában. A Bükki Szeletien kultúra hosszú fejlődését a barlang 1999 és 2004 közötti feltárásain vett mintákon mért 14C dátumok 44/42 ezer év BP és 22 ezer év BP közé helyezik (Ringer 2008-2009). Ennek megfelelően a korai időszaka a Késő Micoquien a késői időszaka pedig a Gravettien kultúrákkal egyidôs a morvaországi kronológiai sorozat szerint (Neruda 2008-2009). Egyidős ugyanakkor számos a Kárpátoktól keletre található régészeti kultúrával is (Noiret 2009: 493-518), amelyeknek a tipológiai elemeit Ringer Árpád (2008-2009: 26) felismerte a Szeleta leletanyagában. A feltételezett kapcsolatokat viszont alá kellene támasztani az érintett darabok kronológiai helyzetének tisztázásával. A levéleszközökön elvégzett újabb technológiai elemzések eredményei alapján a Korai Szeletienhez és a Fejlett Szeletienhez kapcsolható levéleszközök az eltérő technológiájuk miatt

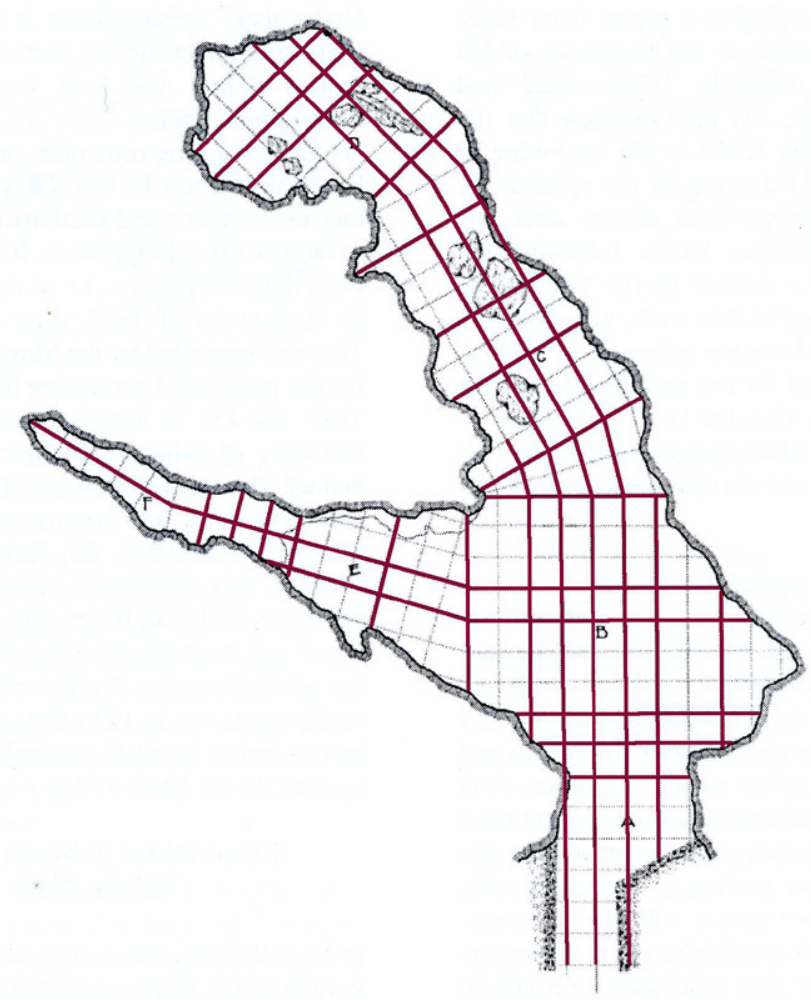

4. ábra. A barlang kitöltésének ismert, Kadić Ottokár és Mottl Mária által felvett metszeteinek elhelyezkedése az I. szint alaprajzára vetítve. Mester 2002: fig. 4 nyomán. // Figure 4. The known profiles of the cave filling, recorded by Ottokár Kadić and Mária Mottl, represented on the I. level plan of the cave. After Mester 2002: fig. 4.

nem füzhetők fel egy származási/fejlődési vonalra, ám egyes darabok rétegtani helyzetében vannak ellentmondások (Mester 2010; 2011). A barlangnak a Fejlett Szeletien kultúrának tekintett anyagát a levélhegyes Gravettien kultúrába is sorolják (Simán 1990; 1995), amiből következik, hogy az ún. alsó kultúrréteg felső részének levélhegyes anyaga marad ebben az olvasatban az egyedüli jelölt arra, amit a nemzetközi kutatás Szeletien kultúrának tekint.

E rövid áttekintésből is látható, hogy a leletek régészeti besorolása, osztályozása, időrendje számos bizonytalanságot hordoz. A barlang a hazai és a nemzetközi ismertsége révén annyira fontos, hogy nem lehet lezártnak tekinteni a kutatásokat addig, amíg nem használtunk ki minden módszert és lehetőséget a kronológiai kérdések tisztázásához.

\section{A Szeleta-barlang kutatásának lehetőségei}

A lelőhely régészeti problémáinak további kutatása két vonalon folyhat: az eddig előkerült leletanyag újabb és újabb szempontú részletes elemzésein keresztül, valamint a megmaradt kitöltésrészeken végzett rétegtani-üledékföldtani vizsgálatok és az azokhoz kapcsolódó új radiometrikus datálások által. Ám a barlang soklépcsős, bonyolult feltárástörténete megnehezíti a mai régészeti munkát. Rendelkezésre állnak a jelentős részben publikálatlan alap- és metszetrajzok (4. ábra), valamint az első ásatássorozat (1906-1913) idején felvett jegyzék (gyűjtőleltár), amelyben minden darabra vonatkozóan rögzítették az előkerülés helyét: a barlangrészt, a négyszöget, a bontási mélységszintet és a réteg jellegét (Mester 2001; 

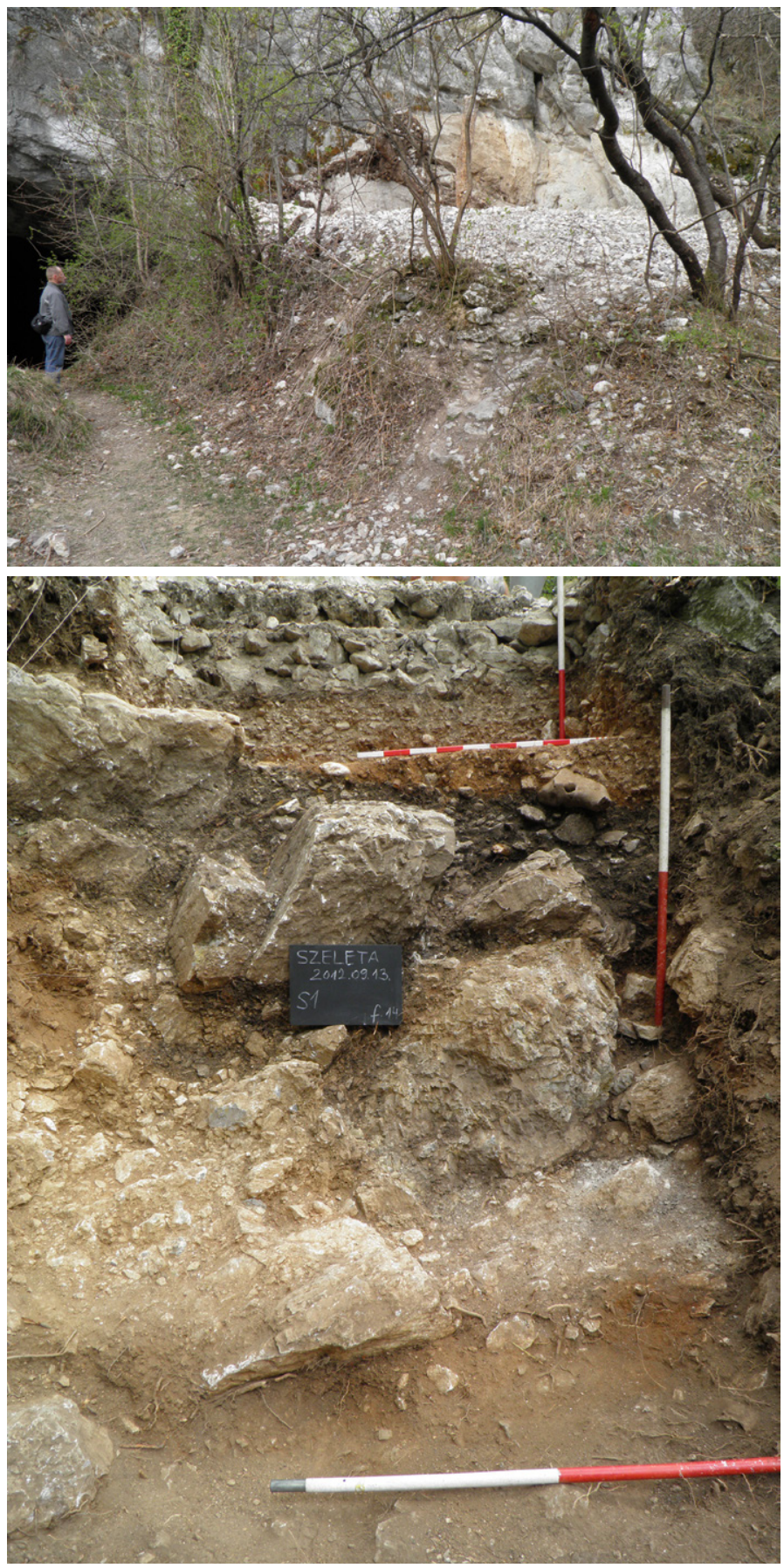

5. ábra. A barlang előtere a mészkődepó eltávolítása után. Fotó: Lengyel Gy. // Figure 5. The cave entrance after the removal of the limestone deposit. Photo: Gy. Lengyel.

6. ábra. Az előtér teraszán 2012-ben feltárt szelvény nyugatról nézve. A rétegsor tetején az 1906-1913 közötti ásatások meddőhányójának rétegei, alatta a nagy mészkőtömbökre rakódva az egykori holocén talaj látható. Fotó: Lengyel Gy. // Figure 6. Western profile of the trench at the entrance, excavatedin 2012. The top layers are middens deposited during the digs between 1906-1913. Below that, the holocene layers are lying on the big limestone blocks. Photo: Gy. Lengyel.

2002). Kadić Ottokár ásatási és dokumentációs módszerének (Kadić 1915: 157-158) ismeretében ezekből az adatokból rekonstruálható a leletek előkerülési helye az ásatási egységeknek megfelelően, ami a kitöltés maximum $0,5 \mathrm{~m}$ vastag részét jelenti a barlangnak egy $4 \mathrm{~m}^{2}$-es területén (Ringer-Mester 2000: 264-265; 2001: 10-11; Mester 2001: 22-24). A 2000 darabból így 1364-ről állapítható meg, hogy melyik rétegből és azon belül melyik szintből származik (Ringer-Szolyák 2004). Mivel Kadić eredeti szándéka a barlang kitöltésének teljes kiásása volt (Mester 2002: 57), az ásatók nem hagytak meg tanúfalat a teljes rétegsorral az utókor számára. Ezáltal a most feltárható leleteknek az egykori rétegsorral való korrelációja nem végezhető el pontosan. Ráadásul a metszetrajzok arra vallanak, hogy a rétegsor valószínúleg sokkal tagoltabb volt, mint ahogy azt a 20. század elején leírták (Ringer 2002; Lengyel et al. 2008-2009).

A meglévő dokumentációk ismeretében a barlangnak két területe alkalmas még régészeti feltárásra. Az egyik a Főfolyosó bal oldala, ahol a 3-as réteg részben és a 2-es réteg teljes vastagságban megtalálható. Azt is biztosan tudjuk, hogy a Főfolyosó hátsó részében a Cseppköves üreg mellett a kitöltés eredeti felszínéhez képest $8 \mathrm{~m}$ mélyen még nem jelentkezik a barlang feneke (Lengyel et al. 2008-2009). A másik terület a barlang előtere, ahol korábban nem folyhatott feltárás az említett mészkődepó miatt. A Szeleta Kultúráért Közalapítvány és a Bükki Nemzeti Park erőfeszítéseinek köszönhetően 2011-re ez a helyzet megváltozott. A Bükki Nemzeti Parknak a területén található barlangok rehabilitációját célul tüző programjának keretében a korábban az ásatásokon felhalmozott kőtörmeléket eltávolították a barlang teraszáról a bejárattól keletre eső oldalon (5. ábra). A bejárattól nyugatra eső oldalon ezt a területrendezést A Szeleta Kultúráért Közalapítvány már korábban elvégeztette.

\section{A Szeleta-barlang 2012. évi ásatása}

2010-ben az Eötvös Loránd Tudományegyetem Régészettudományi Intézete kezdeményezte, hogy a Szeleta új sztratigráfiai kutatását együttmúködés keretében közösen végezzék a barlang tudományos vizsgálatában érintett intézmények: ELTE Régészettudományi Intézet, Herman Ottó Múzeum, Miskolci Egyetem Történettudományi Intézet, A Szeleta Kultúráért Közalapítvány. A meglévő feltárási dokumentációkból arra lehetett következtetni, hogy az előtéren egy értelmezhető vastagságú és kellően tagolt rétegsort lehet feltárni modern módszerekkel. Valószínűnek tûnt, hogy az itt feltárandó sorozatban még azok a felsô rétegek is megtalálhatóak lesznek, amelyeket a barlang belsejében már teljesen eltávolítottak. Az ásatás során a feltárt üledékeket teljes körü üledékföldtani elemzésnek vetjük alá, a rétegsort többféle módszerrel datáljuk és külön figyelmet fordítunk a régészeti leletanyag sztratigráfiai helyzetének tisztázására. A lelőhely jelentőségét jelzi, hogy az új vizsgálatokba két jelenleg futó, a kora felső paleolitikumot érintő nagy nemzetközi kutatási projekt is bekapcsolódott. Az Oxfordi Egyetem kutatócsoportja által vezetett RESET (RESponse of humans to abrupt Environmental Transitions) projektje ${ }^{1}$ azt vizsgálja, hogy az utolsó 100 ezer évben hogyan reagáltak az emberi kultúrák a hirtelen környezeti változásokra. Ehhez az egykori vulkánkitörésekből származó hamumaradványokat (mikrotefra) keresik geokémiai módszerekkel a középső és felső paleolitikus lelőhelyek üledéksorozataiban. Ezek a tefranyomok ráadásul kronológiai markerek is, mivel azonosítható, hogy melyik vulkánkitöréshez tartoznak. A Kölni Egyetem kutatói által vezetett „Our way to Europe: Culture-Environment Interaction and Human Mobility in the Late Quaternary” címü

1 http://c14.arch.ox.ac.uk/reset 
kutatási programja a földtudományok és a régészet módszereivel vizsgálja, hogyan és milyen útvonalakon terjedve érkezett Nyugat-Európába az afrikai bölcsőből a modern ember, és ebben milyen szerepet játszott a kultúra és a környezet egymásra hatása. Ez utóbbi programnak a bekapcsolódása a Szeleta vizsgálatába egy tágabb keretbe, a Miskolci Egyetemnek és a Kölni Egyetemnek a kétoldalú együttmúködésébe illeszkedik.

A meddőhányó sárga rétege alatt az a sötétszürke, humuszos réteg következik, amelyik az 1906-os ásatásokat megelőzően a teraszt borító talajtakaró lehetett, amit megerősítenek a benne előkerült őskori cserepek is. A szelvény keleti metszetfalában a sötétszürke réteg alatt közvetlenül nagy szikladarabok fekszenek, ami nem adott túl sok reményt arra, hogy a szelvényben érintetlen jégkori réteget találjunk (6. ábra). A Mottl-féle metszetrajzokat és a barlang előterének morfológiai viszonyait tanulmányozva azonban arra a következtetésre jutottunk, hogy kelet felé a sziklák szintje esik, s ott az egykori talajtakaró alatt in situ üledéket találhatunk. Ezért az első szelvényünket kelet felé megtoldottuk egy $2 \mathrm{~m}$ $\times 1,5 \mathrm{~m}$-es területen. Ebben a szelvényben a meddőhányó rétegek és a sötétszürke holocén talajréteg elbontása után egy sárgás-szürkés rétegre bukkantunk, amely gazdag volt állatcsontokban (7. ábra). Ezt a réteget $1 \mathrm{~m}^{2}$-es területen $5 \mathrm{~cm}$ vastagságban tártuk fel, ahol a csontok mellett néhány pattintott kőeszközt is találtunk. Ez a felfedezés reményt ad a kutatás sikeres folytatására.

\section{Felhasznált irodalom}

Adams, B. 1998. The Middle to Upper Paleolithic transition in Central Europe. The record from the Bükk Mountain region. BAR International Series 693, Oxford: Archaeopress.

Allsworth-Jones, P. 1986. The Szeletian and the transition from Middle to Upper Palaeolithic in Central Europe. Oxford: Clarendon Press.

Gábori M. 1982. A Bükk hegység paleolitikumának mai problémái. Herman Ottó Múzeum Közleményei 20: 1-7.

Hillebrand, J. 1935. Die Ältere Steinzeit Ungarns. Archaeologia Hungarica 17, Budapest: Magyar Történeti Múzeum.

Kadić O. 1915. A Szeleta-barlang kutatásának eredményei. A Magyar kir. Földtani Intézet Évkönyve 23(4): 151-278.

Kadić, O. 1934. Der Mensch zur Eiszeit in Ungarn. Mitteilungen aus dem Jahrbuch der kgl. Ungarischen Geologischen Anstalt 30: 1-147.

Lengyel, Gy., Mester, Zs. 2008. A new look at the radiocarbon chronology of the Szeletian in Hungary. In: Jöris, O., Adler, D. S. (eds.), Dating the Middle to Upper Palaeolithic boundary across Eurasia. Proceedings of Session C57, 15th UISPP Congress, Lisbon, Portugal, 2006. Setting the record straight: Toward a systematic chronological understanding of the Middle to Upper Palaeolithic boundary in Eurasia. Eurasian Prehistory 5(2): 73-83.

Lengyel, Gy., Szolyák, P., Pacher, M. 2008-2009. Szeleta Cave earliest occupation reconsidered. Praehistoria 9-10: 9-20.

Mester, Zs. 2001. Bükki paleolitikus barlangi lelőhelyek régészeti revíziója: három esettanulmány. Herman Ottó Múzeum Évkönyve 40: 21-38.

Mester,Zs. 2002. Excavations at Szeleta Cave before 1999: methodology and overview. Praehistoria 3: 57-78.

Mester, Zs. 2010. Technological analysis of Szeletian bifacial points

2 http://www.sfb806.uni-koeln.de
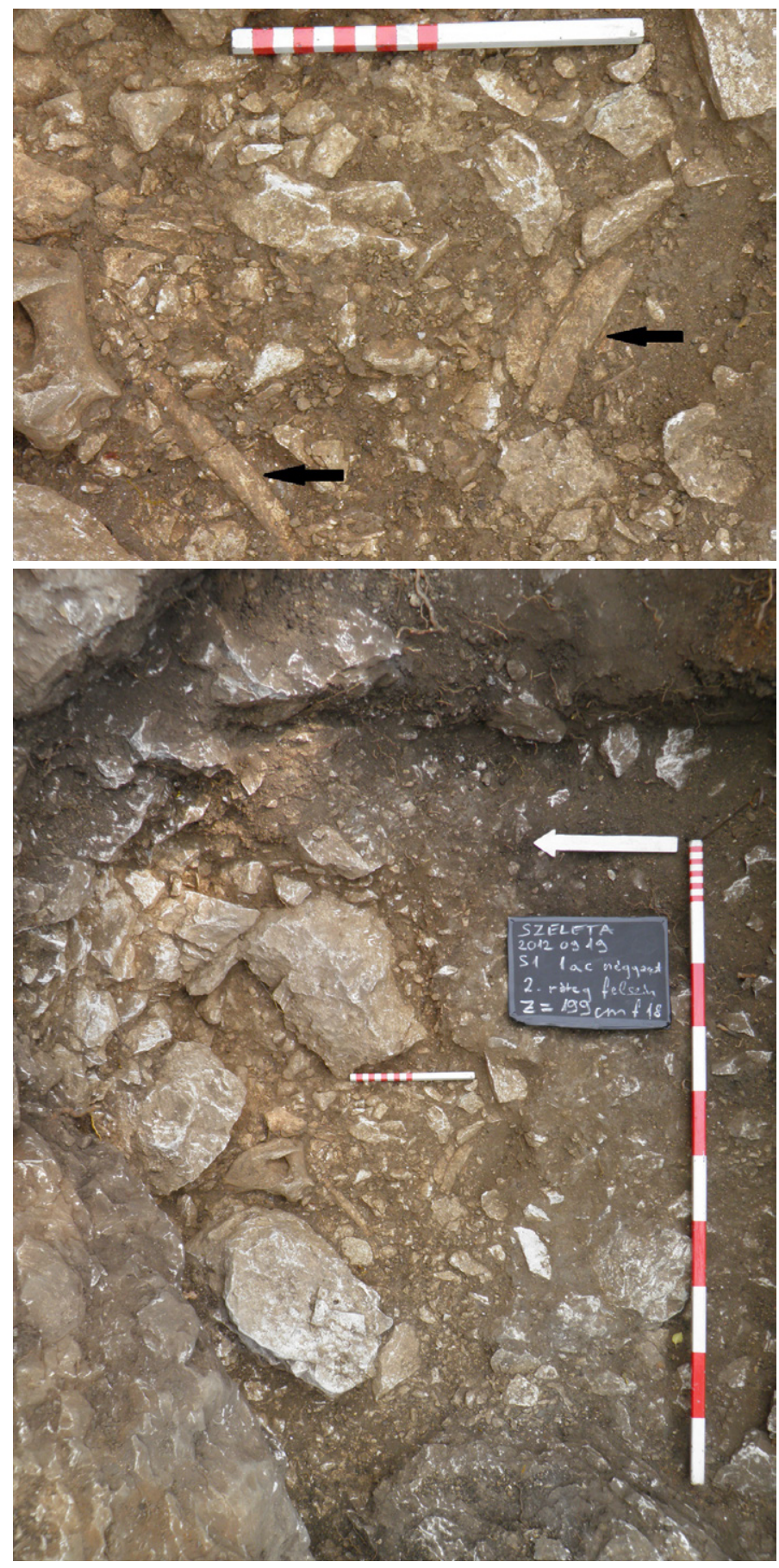

7. ábra. Eredeti helyzetű pleisztocén réteg állatcsontokkal az előtéren feltárt szelvényben. Fotó: Lengyel Gy. // Figure 7. In situ Pleistocene layer in the trench excavated at the entrance. Animal bones are indicated with arrows. Photos: Gy. Lengyel.

from Szeleta Cave (Hungary). Human Evolution (Firenze) 25(1-2): 107-123.

Mester Zs. 2011. A magyarországi középső és felső paleolitikum bifaciális levéleszközeinek technológiája. In: T. Biró K., Markó A. (szerk.), Emlékkönyv Violának. Tanulmányok T. Dobosi Viola tiszteletére. Papers in honour of Viola T. Dobosi. Budapest, 15-41.

Neruda, P. 2008-2009. Moravia during OIS 3: cultural relations. Praehistoria 9-10: 125-147.

Noiret, P. 2009. Le Paléolithique supérieur de Moldavie. Essai de synthèse d'une évolution multiculturelle. E.R.A.U.L. 121, Liège: Université de Liège.

Pelikán P. 2002. Földtani felépítés, rétegtani áttekintés. In: Baráz Cs. 
(ed.), A Bükki Nemzeti Park. Hegyek, erdók, emberek. Eger: Bükki Nemzeti Park Igazgatóság, 23-49.

Ringer, Á. 1989. L'origine du Szélétien de Bükk en Hongrie et son évolution vers le Paléolithique supérieur. Anthropologie (Brno) 27/2-3: 223-229.

Ringer, Á. 2002. The new image of Szeleta and Istállós-kő caves in the Bükk Mountains: a revision project between 1999-2002. Praehistoria 3: 47-52.

Ringer, Á. 2008-2009. Nouvelles données sur le Szélétien de Bükk. Praehistoria 9-10: 21-34.

Ringer, Á., Mester, Zs. 2000. Résultats de la révision de la grotte Szeleta entreprise en 1999 et 2000. Anthropologie (Brno) 38: 261-270.

Ringer Á., Mester Zs. 2001. A Szeleta-barlang 1999-2000. évi régészeti revíziójának eredményei. Herman Ottó Múzeum Évkönyve 40: 5-19.

Ringer Á., Szolyák P. 2004. A Szeleta-barlang tűzhelyeinek és paleolit leleteinek topográfiai és sztratigráfiai eloszlása. Adalékok a leletegyüttes újraértékeléséhez. Herman Ottó Múzeum Évkönyve 43: $13-32$

Simán, K. 1990. Considerations on the "Szeletian unity". In Kozlowski, J. K. (éd.) Feuilles de pierre. Les industries à pointes foliacées du Paléolithique supérieur européen. E.R.A.U.L. 42, Liège: Université de Liège, 189-198.

Simán, K. 1995. La grotte Szeleta et le Szélétien. In: Les industries à pointes foliacées d'Europe centrale. Actes du Colloque de Miskolc, 10-15 septembre 1991. Paléo, Supplément $n^{\circ}$ 1: 37-43. https://doi. org/10.3406/pal.1995.1378

Svoboda, J., Simán, K. 1989. The Middle-Upper Paleolithic transition in Southeastern Central Europe (Czechoslovakia and Hungary). Journal of World Prehistory 3: 283-322. https://doi.org/10.1007/ BF00975325

Székely K. 2002. Fokozottan védett barlangok. In: Baráz Cs. (szerk.), A Bükki Nemzeti Park. Hegyek, erdók, emberek. Eger: Bükki Nemzeti Park Igazgatóság, 177-193.

Vértes L. 1965. Az ôskókor és az átmeneti kókor emlékei Magyarországon. A Magyar Régészet Kézikönyve 1, Budapest: Akadémiai Kiadó. 